\title{
Preliminary analysis of water pollution in a small lake in Western Mexico
}

\author{
T. Greenberg ${ }^{1}$, H. Shear ${ }^{1}$, J. de Anda Sanchez ${ }^{2}$ \\ \& M.-A. Ortiz-Jiménez ${ }^{3}$ \\ ${ }^{1}$ Department of Geography, University of Toronto, Canada \\ ${ }^{2}$ Centro de Investigacion y Asistencia en Tecnología y Diseño, A.C., \\ Normalistas 800, 44270 Guadalajara, Jalisco, México \\ ${ }^{3}$ Instituto Tecnológico de Tepic, Av. Tecnológico 2595, 63175 Tepic, \\ Nayarit, México
}

\begin{abstract}
Lake Zapotlán is a small (1100 ha) endorheic lake in western Mexico. The lake is an internationally recognized RAMSAR site, home to many migratory species of waterfowl. It receives point source pollution from partially treated sewage from Ciudad Guzman (population 85,000) and Gomez Farias (population 12,000 ), as well as non-point sources, including storm water, agricultural, and land clearing runoff from numerous farms and from deforestation surrounding the lake. Anthropogenic activities in the basin are putting the ecological sustainability of the lake at risk. The lake is hypertrophic and exhibits blooms of green algae and possibly cyanobacteria throughout much of the year. Along the shoreline of the lake, extensive beds of bulrush, called locally "tule" (Typha latifolia), are found, as well as floating mats of water hyacinth (Eichhornia crassipes) likely due to excessive nutrient levels in the lake. This paper compares nutrient levels (nitrogen and phosphorus) for three different years since 1994.
\end{abstract}

Keywords: eutrophication, tropical lakes, aquatic weeds, fisheries production, flux of nutrients, Zapotlán, non-point and point source pollution.

\section{Introduction}

Lake Zapotlán is located in the south of Jalisco State, Mexico, between $19^{\circ} 34^{\prime}$ and $19^{\circ} 53^{\prime}$ north latitude and $103^{\circ} 24^{\prime}$ ' and $103^{\circ} 38^{\prime}$ west longitude (Figure 1). 
The second largest city in Jalisco State, Ciudad Guzman, is located in the Lake Zapotlán Basin with a population of about 85000 inhabitants and an annual growth rate of $1.5 \%$ [1]. Lake Zapotlán was listed as a RAMSAR site in 2005 in recognition of its important migratory waterfowl and wetlands surrounding the lake [2].

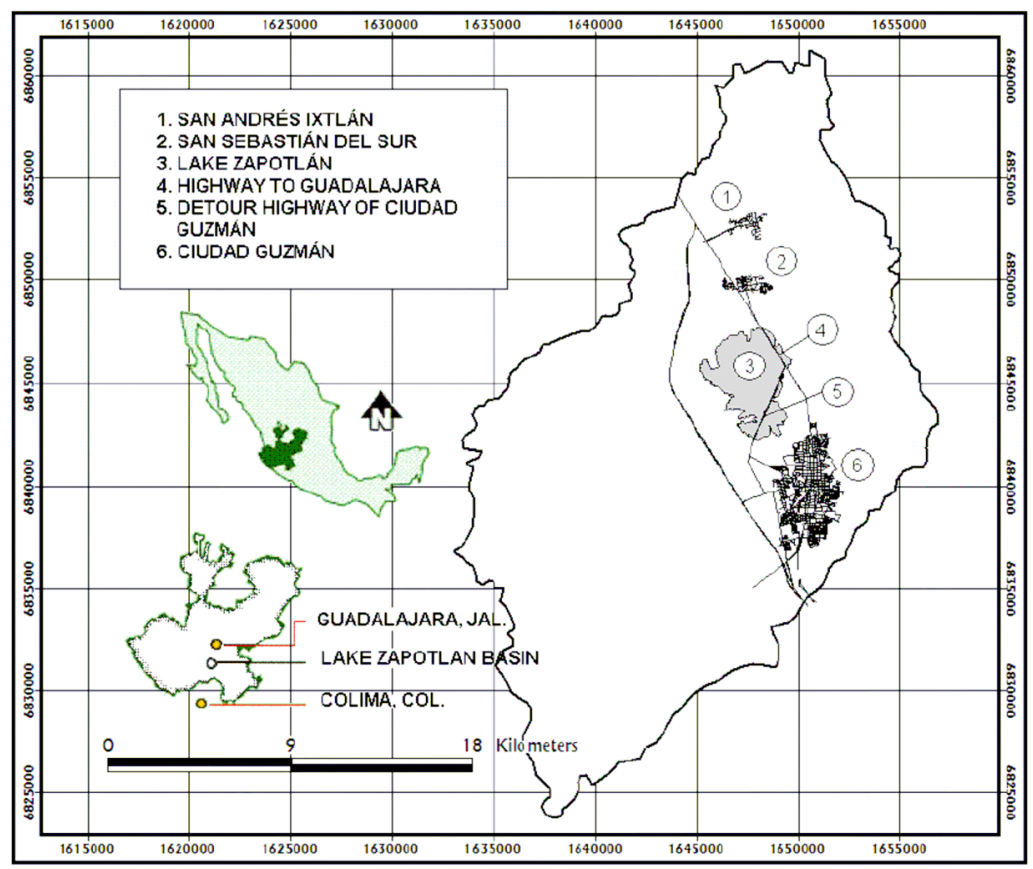

Figure 1: Geographical location of the Lake Zapotlán Basin.

There has been a marked degradation of the water quality in Lake Zapotlán during the last few decades driven largely by non-point and point source inputs. Discharge from essentially untreated municipal sewage from the nearby towns, construction of municipal roads crossing the lake, deforestation, and runoff from numerous farms are some potential sources for the degraded water quality [3]. These processes have caused an increase in nutrients in the lake, resulting in an abundance of rooted and floating aquatic vegetation known as bulrush cotton tail "tule" (Typha latifolia) and water hyacinth (Eichhornia crassipes). There have also been frequent blooms of green algae, and possibly cyanobacteria (Anabaena flos-aquae), a species that may cause health and odour problems [4].

Past research on Lake Zapotlán includes an unpublished limnological survey of the lake in 1994 [5], nutrient/food chain modelling [6], an estimation of trophic states in warm tropical lakes using GPSS simulation [7], and a hydrological balance of the lake in [8].

The limnological survey data from 1994 and the nutrient/food chain modelling study contain nutrient data that were used to compare total phosphorus 
and total nitrogen data with data collected by two of the authors (TG and HS) in October, 2007 in Lake Zapotlán. A comparison of past nutrient levels in the lake has never been determined, nor has a nutrient mass balance of phosphorus and nitrogen in the lake. The purpose of this paper is to compare nutrient levels in 1994, 2003 and 2007, and to discuss the work necessary to determine a nutrient mass balance for nitrogen and phosphorus, including the role of biota (tule, water hyacinth, fish) in regulating nutrient levels.

\section{Methods and study site description}

\subsection{Study area}

Lake Zapotlán is the main water reservoir to a group of integrated neighbouring closed basins such as Lake Sayula, Lake San Marcos, and Lake Atotonilco [6]. The topography varies from an elevation of $1497 \mathrm{~m}$ amsl at the surface of the lake, to $3900 \mathrm{~m}$ amsl at the El Aguila Peak located in the volcano Nevado de Colima surrounding the lake [8].

The lake is a small (1100 ha), shallow, endorheic freshwater lake with only a few intermittent streams. The only permanent water source entering the lake is sewage coming from Ciudad Guzman, San Sebastian, and San Andres Ixtlan [8]. The water column is considered completely mixed due to permanent winds, the shallow nature of the lake, and its short residence time of about seven months [8]. The main outflows of the lake are water extractions for irrigation $(37.4 \%)$, evaportranspiration (33.6\%), and evaporation (29\%) [9]. The basin has about 1576 ha of irrigated land, of which 700 ha are irrigated with lake water, and the remainder with groundwater [9]. The main water uses in the basin are for irrigation and watering crops and livestock (90\%), industrial use (7\%), and urban use $(3 \%)$ [10].

The Mexican National Water Commission classifies the quality of groundwater as suitable for drinking [11]. However, due to frequent earthquakes in the region from volcanic and tectonic origin, the sewage system of Ciudad Guzman has been affected by leaks that allow flows to the aquifers, contaminating them by infiltration [8]. Some traces of methane have also been found in some wells used for irrigation and water supply for the urban areas, resulting in some health problems among the population [12].

Poor water quality has also been observed resulting from building a highway over the lake (see Figure 1), resulting in stagnant zones in the lake. The bulrush cotton tail (Typha latifolia), called 'tule' by the local people, and water hyacinth (Eichhornia crassipes) have taken advantage of the nutrient rich and stagnant waters, and had managed to cover almost $70 \%$ of the surface of the lake by 1993 before action was taken by the municipality to remove these plants. They now cover $30 \%$ of the littoral zone in the lake (Figure 2) [8]. This extensive plant growth may have affected the local fishery. The fishery is based on two introduced species, the common carp (Cyprinus carpio) accounting for $68 \%$ of the catch and tilapia (Oreochromis aureus) accounting for 32\% [8]. Fishery production has decreased almost 75\% (Figure 3) [13]. 


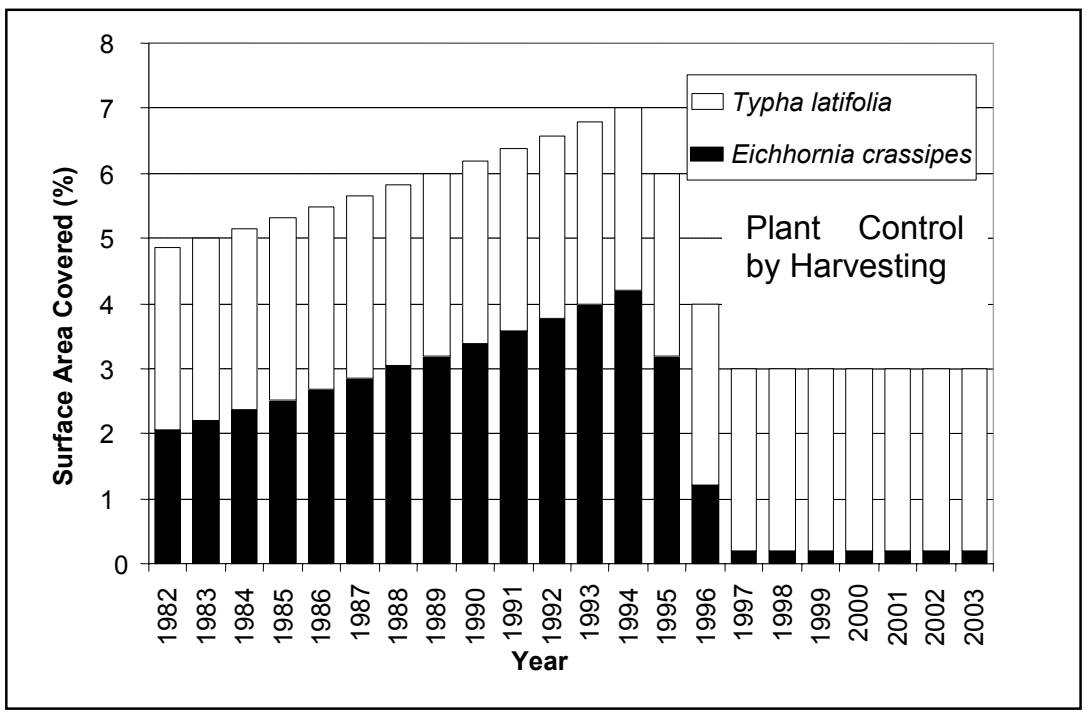

Figure 2: $\quad$ Surface area of the lake covered with aquatic plants.

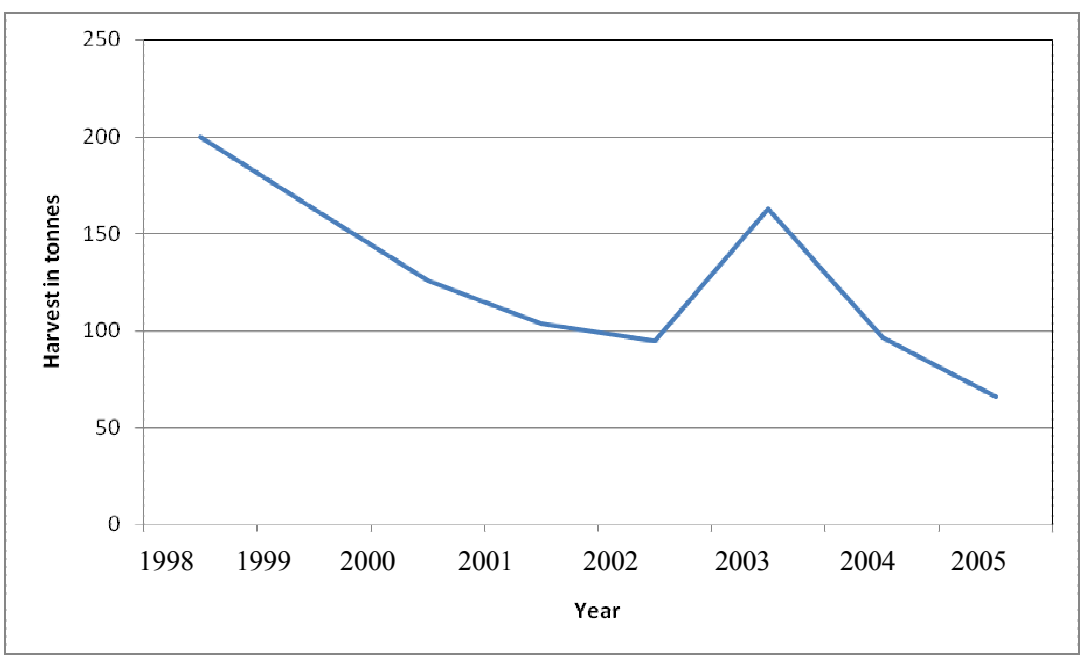

Figure 3: $\quad$ Fishery production in Lake Zapotlán.

\subsection{Methods}

Fourteen water samples were collected from twelve stations on the surface of Lake Zapotlán and in surrounding tributaries in stratified random sampling transects (Figure 4). Seven stations were sampled in the littoral zone by a small fishing boat, and one from the limnetic zone (station 4), at the deepest point in the lake. The samples were collected from these stations because the depth of the 
lake only ranged from $1.4 \mathrm{~m}$ to $4.1 \mathrm{~m}$. Four inflowing streams were sampled by walking to the site (stations 1,9,11, and 13), one of which (station 13) consisted of untreated sewage from the local waste water treatment plant. For this present work, however, only data from the lake were analyzed. The seven samples in the littoral zone were collected within $50 \mathrm{~m}-200 \mathrm{~m}$ of shore. It was not possible to get closer to shore due to excessive mats of 'tule' (Typha latifolia). Stations were located with a GPS navigator and stored for future site visits. Altitude, dissolved oxygen, air temperature, water temperature, conductivity, $\mathrm{pH}$, dissolved organic solids, and turbidity measurements were also taken at each station.

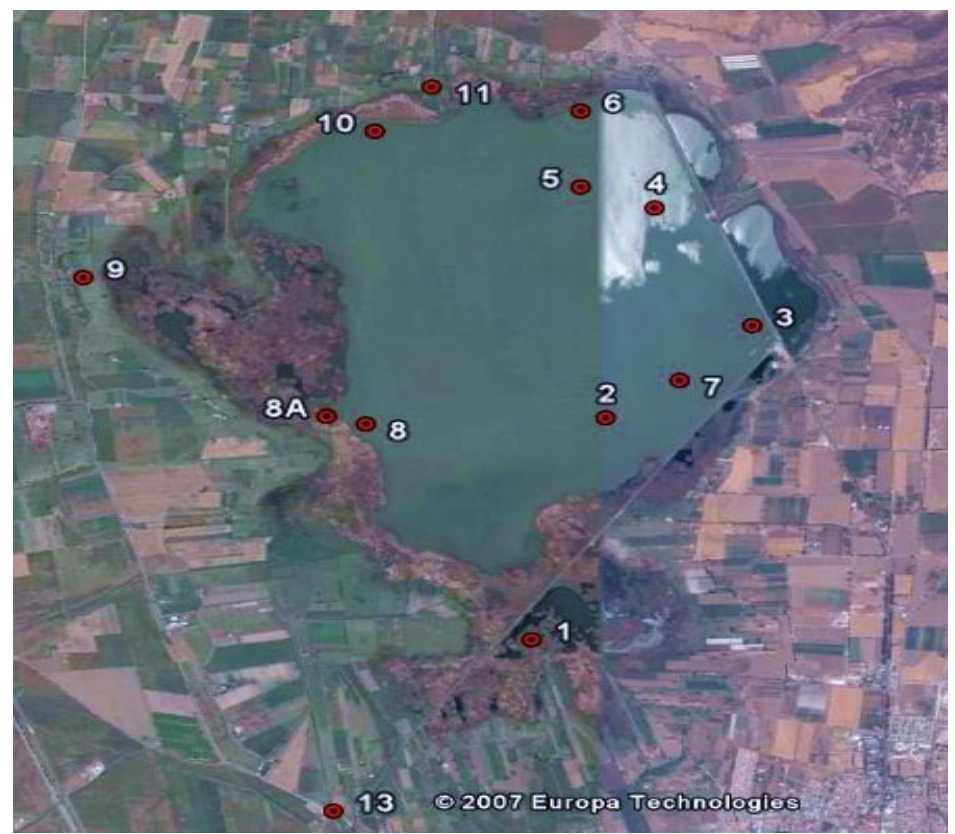

Figure 4: $\quad$ Sampling points used in Lake Zapotlán, Jalisco, Mexico.

The water samples were collected over three days, October, 6, 7, and 8, 2007 towards the end of the rainy season. A $4 \mathrm{~L}$ jug was used to collect water for both the phosphorus and nitrogen analysis, using a surface grab sample. A Kemmerer bottle was used to collect depth samples at station 4 . Samples were then acidified with $2 \mathrm{ml} / \mathrm{L}$ sulphuric acid, and were stored at $4^{\circ}$ Celcius and taken to a Mexican federal laboratory (Centro de Investigación y Asisténcia en Tecnología y Diseño del Estado de Jalisco (CIATEJ)) in Guadalajara for analysis. Half of each sample was filtered using $0.45 \mu \mathrm{m}$ nitrocellulose membrane filters and a vacuum pump. Total phosphorus and nitrogen were analyzed using Mexican National Standards [14].

The nutrient studies in 1994 and 2003 both have nutrient sampling data from October, and these were used for comparison with 2007 results. Only those stations that were coincident with each other for all three years were selected for 
analysis. Analytical methods for 1994 are based on National Institute of Ecology standards [15]. Analyses of the 2003 samples are based on the same standards as 2007, and were carried out at the CIATEJ laboratory.

\section{Results}

Basic physical and chemical parameters for some representative lake stations are presented in Table 1.

Table 1: $\quad$ Basic physical and chemical parameters for some representative lake stations.

\begin{tabular}{|c|c|c|c|c|c|c|c|}
\hline Parameter & Units & $\begin{array}{l}\text { Station } \\
2\end{array}$ & $\begin{array}{l}\text { Station } \\
3\end{array}$ & $\begin{array}{l}\text { Station } \\
4\end{array}$ & $\begin{array}{l}\text { Station } \\
4\end{array}$ & $\begin{array}{l}\text { Station } \\
8\end{array}$ & $\begin{array}{l}\text { Station } \\
10\end{array}$ \\
\hline Date & $\begin{array}{l}\text { yyyy- } \\
\text { mm- } \\
\text { dd }\end{array}$ & $\begin{array}{l}2007- \\
10-06\end{array}$ & $\begin{array}{l}2007- \\
10-05\end{array}$ & $\begin{array}{l}2007- \\
10-05\end{array}$ & $\begin{array}{l}2007- \\
10-07\end{array}$ & $\begin{array}{l}2007- \\
10-06\end{array}$ & $\begin{array}{l}2007-10- \\
05\end{array}$ \\
\hline Lake Depth & $\mathrm{m}$ & 3.37 & 3.7 & 4.1 & 4.1 & 1.5 & 1.8 \\
\hline Sample Depth & $\mathrm{m}$ & 0.5 & 0.5 & 0.5 & 3.5 & 0.5 & 0.5 \\
\hline $\begin{array}{l}\text { Water } \\
\text { Temperature }\end{array}$ & ${ }^{\circ} \mathrm{C}$ & 26.6 & 27 & 25.7 & 25.7 & 24.3 & 26.9 \\
\hline Conductivity & $\mathrm{uS} / \mathrm{cm}$ & 679 & 690 & 683 & 683 & 686 & 681 \\
\hline $\begin{array}{l}\text { Dissolved } \\
\text { Oxygen }\end{array}$ & $\mathrm{mg} / \mathrm{l}$ & 10.53 & 9.81 & 8.76 & 8.76 & 6.25 & 8.83 \\
\hline $\mathrm{pH}$ & & $\begin{array}{l}\text { No } \\
\text { sample }\end{array}$ & 8.73 & 8.86 & 8.86 & $\begin{array}{l}\text { No } \\
\text { data }\end{array}$ & 8.97 \\
\hline Turbidity & $\mathrm{cm}$ & $\begin{array}{l}\text { No } \\
\text { sample }\end{array}$ & 35 & 28 & 28 & $\begin{array}{l}\text { No } \\
\text { data }\end{array}$ & 26 \\
\hline $\begin{array}{l}\text { Total Dissolved } \\
\text { Solids }\end{array}$ & $\mathrm{mg} / \mathrm{l}$ & 762 & 768 & 763 & 763 & 768 & 760 \\
\hline
\end{tabular}

It is apparent from these data that the lake is horizontally and vertically well mixed with temperature. Variations in dissolved oxygen, $\mathrm{pH}$ and turbidity correlate with the location of the station near stands of "tule", or in very shallow water. The lake is shallow, but at the deepest station (4) a depth profile shows that the lake is well mixed vertically.

The data for total phosphorus show some horizontal variability in concentrations in all years analyzed. Furthermore, a comparison of the average phosphorus (figure 5) concentrations in October 1994, 2003, and 2007 demonstrates a large difference between concentrations in 2003 and those in 1994 and 2007. The 1994 phosphorus levels average $0.11 \mathrm{mg} / \mathrm{l}$, the 2003 levels average ten times higher at $1.15 \mathrm{mg} / \mathrm{l}$, and 2007 values average $0.23 \mathrm{mg} / \mathrm{l}$. There has been an apparent increase in average total phosphorus levels in the lake since 1994. Values for total phosphorus in sediments in samples taken in 2007 ranged from 70.4 to $552.9 \mathrm{ppm}$.

The results for total nitrogen concentrations for the same three years are shown in Figure 6. Here nitrogen concentrations are similar for 1994 and 2003, but both are consistently lower than 2007 data. The 1994 total $\mathrm{N}$ values average 
$1.4 \mathrm{mg} / \mathrm{l}$. The average concentration of total nitrogen for $2003 \mathrm{was} 1.4 \mathrm{mg} / \mathrm{l}$, and concentrations are similar at all stations. In 2007, however, average total nitrogen values are $3.4 \mathrm{mg} / \mathrm{l}$. It should be noted that station 10 is near the outfall of the Gomez Farias wastewater treatment plant. There has been an apparent increase in average total nitrogen levels in the lake in the past 5 years. Values for total nitrogen in sediments ranged from 1400 to $2900 \mathrm{ppm}$.

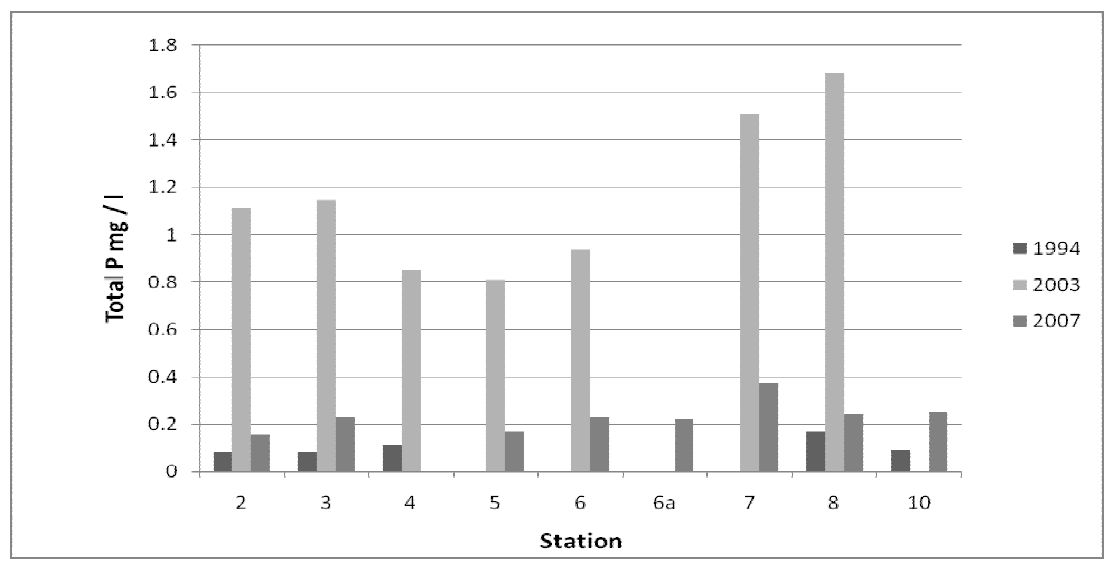

Figure 5: Comparison of total phosphorus levels for October of 1994, 2003, and 2007.

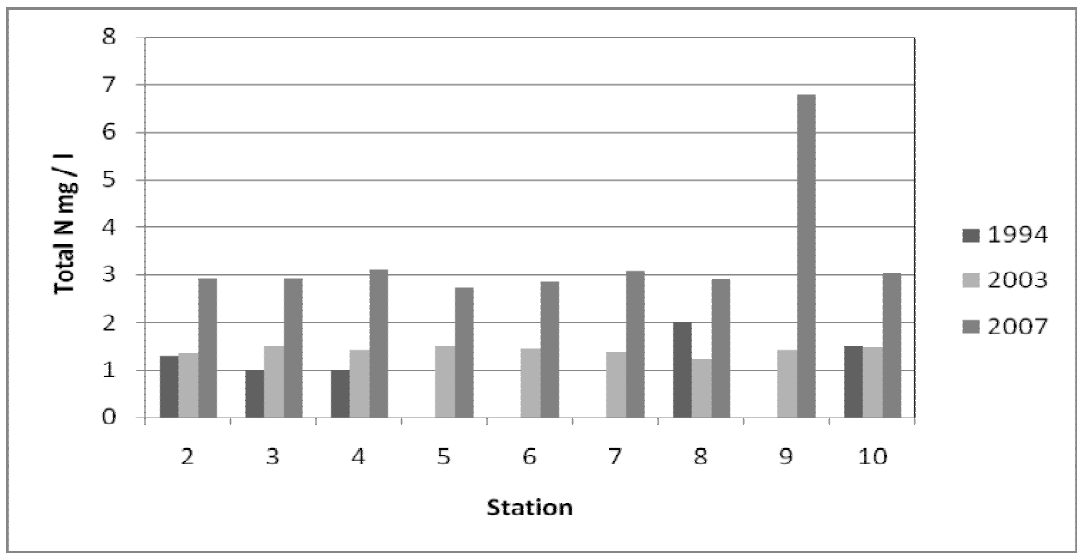

Figure 6: Comparison of total nitrogen levels for October of 1994, 2003, and 2007.

\section{Discussion}

There has been an apparent increase in total phosphorus concentration over the time period in question, although the very high concentrations in 2003 need to be examined in light of runoff patterns. Ortiz et al. [8] indicated that $53.3 \%$ of the 
annual inflow to Lake Zapotlán comes from runoff, whereas sewage discharge accounts for $11.38 \%$ of the annual inflow to the lake. Furthermore they point out that average surficial runoff to Lake Zapotlán from 1982-2003 was $18.9 \mathrm{Mm}^{3}$. In 1994, however, that runoff was just $7 \mathrm{Mm}^{3}$, whereas in 2003 it was $17.5 \mathrm{Mm}^{3}$. This would have resulted in far less total phosphorus entering the lake from surficial runoff in 1994 than in 2003, possibly explaining the lower phosphorus concentrations in 1994. The runoff data for October 2007 are unavailable at the time of writing, so it is not possible to consider the role of runoff in terms of the phosphorus concentrations for 2007. Nevertheless, the total phosphorus concentrations in 2007 are consistently higher than in 1994. Given that the growth in human population is $1.5 \%$ [3], and that the wastewater treatment plants operate at very low efficiency [4], the loading of phosphorus, and hence the concentrations of phosphorus in the lake, are likely to continue to increase. Lake Zapotlán presently has total phosphorus concentrations $(>0.05 \mathrm{mg} / \mathrm{l})$ that would result in it being classified as eutrophic according to standards established in many US states [16]. In addition, the sediments contain 70.4 to $552.9 \mathrm{ppm}$ total phosphorus. There is the potential for sediment resuspension, given the shallow nature of the lake, and release of phosphorus to the water column.

The total nitrogen concentrations have shown an increase since 1994. At these concentrations, total nitrogen was at or below the standards for US states [16] in 1994 and 2003, but exceeded most standards $(>1.0 \mathrm{mg} / \mathrm{l})$ in 2007 . Total nitrogen concentrations in sediment are from 1400 to $2900 \mathrm{ppm}$, so that a potential source of nitrogen release to the water column exists here.

\section{Conclusions}

This preliminary analysis of historical and recently collected data shows that there are increasing trends in both total phosphorus and total nitrogen in Lake Zapotlán. Both total $\mathrm{P}$ and total $\mathrm{N}$ concentrations presently exceed US EPA standards for these parameters, indicating that the lake is polluted. These trends could indicate impacts of human population growth and waste discharge to the lake, expansion of agriculture into areas on steep slopes unsuitable for such a purpose, and unregulated destruction of forests [Shear personal observation].

Further work on Lake Zapotlán will determine the main sources and sinks of phosphorus and nitrogen within the lake basin. For example, the role of sediments in acting as a source or sink for nutrients will be examined, as will the function of "tule" in absorbing or releasing nutrients from / to the lake. The role of excessive nutrients in the lake on the production of blooms of green algae and cyanobacteria needs to be examined. The nutrient status of the lake on the decline in fishery production is unknown, and requires further investigation.

\section{References}

[1] Instituto Nacional de Estadistica Geografia e Informatica (INEGI). XII Censo General de Poblacion y Vivienda, INEGI, Mexico, 2000.

[2] RAMSAR. http://www.ramsar.org/profile/profiles_mexico.htm Site updated 2007-05-21. 
[3] Oritz-Jimenez, M.A. Ph.D. Thesis. Modelo de Nutrientes-Cadena Alimentica Del Lago de Zapotlán, México. Centro de Investigación y Asistencia en Tecnologúa Diseño del Estado de Jalisco. 155 pp. 2006.

[4] de Anda, J. Personal communication, 3 November, 2007. Research Scientist. Centro de Investigacion y Asistencia en Tecnología y Diseño, Guadalajara, Jalisco, México.

[5] Universidad de Guadalajara. Limnologia de la Laguna de Zapotlán. Coordinación General de Ecología y Educación Ambiental, Centro Universitario de Ciencias Biológicas y Agropecuarias Division de Ciencias Biológicas, Instituto de Limnología. Unpublished internal report. November 1994.

[6] Oritz-Jimenez, M.A., De Anda, J. \& Maniak, U. Estimation of Trophic States in Warm Tropical Lakes and Reservoirs of Latin America by Using GPSS Simulation. Interciencia, 31(5), pp. 1-6. 2006 a.

[7] Oritz-Jimenez, M.A., De Anda, J. \& Shear, H. Nutrients/food chain model for Lake Zapotlán (Mexico). Intl. J. River Basin Management, 4(2), pp. 125-135. 2006 b.

[8] Oritz-Jimenez, M.A., De Anda, J. \& Shear, H. Hydrological Balance of Lake Zapotlán, Mexico. Journal of Environmental Hydrology, 13(5), pp. 1-16. 2005.

[9] Comision Estatal de Agua y Saneamiento del Gobierno del Estado de Jalisco (CEASJ). Plan Maestro de la Laguna de Zapotlán. Guadalajara, Jalisco, Mexico, pp. 111, 2003.

[10] Instituto Nacional de Estadistica Geografia e Informatica (INEGI). Estudio Hidrologico del Estado del Jalisco, Segunda edicion. INEGI, Mexico, pp. 176.

[11] National Water Commission (CNA). Meteorological monthly reports. Comision Nacional del Agua, Department of Hydrometry, Meteorological station of Ciudad Guzman, Mexico, 2004.

[12] University of Guadalajara. University Gazette, Social Communication. Universidad de Guadalajara, Guadalajara, Mexico. Unpublished report. 1999.

[13] CUSUR Unpublished proceedings of the $5^{\text {th }}$ International Workshop on Lake Rehabilitation. Ciudad Guzman. 2005.

[14] Secretaría de Medio Ambiente y Recursos Naturales. Normas Mexicanas Vigentes. December 2007. http://www.semarnat.gob.mx/leyesynormas/ Pages/normasoficialesmexicanasvigentes.aspx

[15] NOM-AA-26-1980 (total N) and NOM-AA-50-1978 (total P). National Institute of Ecology. http:/www.ine.gob.mx/ueajei/publicaciones/gacetas/ 188/nte9.html

[16] Environmental Protection Agency. Survey of States, Tribes and Territories Nutrient Standards 2003. http://www.dep.state.fl.us/water/wqssp/ nutrients/docs/state_standards.pdf 